American Journal of Environmental Sciences 5 (2): 145-155, 2009

ISSN 1553-345X

(C) 2009 Science Publications

\title{
Strengthening Conservation in the Tropics: The Water Canon of Costa Rica
}

\author{
${ }^{1}$ Francisco Benavides and ${ }^{2}$ John N. Veenstra \\ ${ }^{1}$ Environmental Science Program, Oklahoma State University, \\ 002 LSE, Stillwater, OK 74078 \\ ${ }^{2}$ School of Civil and Environmental Engineering, Oklahoma State University, \\ 207 ES, Stillwater, OK 74078
}

\begin{abstract}
Problem statement: The tropics contain primary forests with a significant value for society, as they provide services such as carbon sequestration, soil conservation, bio-prospecting, water storage and others. Competing land uses have not favored conservation during the last several decades and therefore the need for an effective public policy instrument to curtail forest loss is evident. Approach: This article analyzed a policy intended to augment the funds for subsidizing forest conservation in Costa Rica through a tax on the consumption of potable water. This potable water canon was compared on the basis of legitimacy criteria to the alternative of imposing a tax on the exploitation of marginal lands. The analysis was based on comparing the perceptions different stakeholders have toward deforestation and its potential solutions, which result into different frames, or views regarding the problem. The perceptions were obtained from semi-structured interviews of individuals representing the central and local governments, national and local non-governmental organizations, the private sector, academia and political parties. Results: Overall, the water canon is a superior policy from the point of view of technical implementability and political feasibility. The regulation was expected to increase the forest cover in private hands in a more effective way than the tax on marginal lands, while keeping government expenditures to a minimum. The policy context is one of high expert and social trust and low government trust, requiring substantive stakeholder education and the creation of feedback mechanisms to increase acceptability during the implementation period. Conclusion: If approved by the Costa Rican Congress, the water canon will become an innovative conservation policy from which other developing countries will be able to obtain valuable lessons.
\end{abstract}

Key words: Deforestation, Costa Rica, conservation policy, subsidies

\section{INTRODUCTION}

The tropics are home to some of the last primary forests on Earth, many of which continue to disappear at an alarming speed, even though they have an immense value for providing society with an array of services such as carbon sequestration and storage, soil conservation, bio-prospecting, water storage, ecotourism and others ${ }^{[6,16]}$

Although $28 \%$ of the surface area in Costa Rica enjoys some type of preservation status, the country lost more than $50 \%$ of its forest cover during the last century ${ }^{[9]}$. By the mid 1990s pastures covered about $47 \%$ of the territory, while some $40 \%$ of it was still forested $^{[3]}$. The government reacted with the 1996 amendments to the Forestry Law, which created the Environmental Service Payment (ESP), a subsidy to be given to owners of forested lands as a compensation for the services they provide to society at large. During the past eight years, about $50 \%$ of pastures were left to recover into forest, perhaps due to the ESP, but also because of a fall in international beef prices that made cattle production a less profitable business ${ }^{[8]}$. The extent to which the ESP has been an effective mechanism is questionable, considering that several pastures still exist today in fragile, highly erodible and sloped terrains ${ }^{[6]}$. An insufficient ESP budget may be part of the problem. Most of the funding comes from a 3.5\% tax on fossil fuels, but that can only subsidize one fifth of the current supply of land for conservation ${ }^{[22]}$. Moreover, the push by the government to sign free trade agreements may open up new markets for Costa Rican beef and that could stop reforestation efforts and put pressure on the last remaining forested tracts in private hands.

The Environmental Affairs Commission of the Costa Rican Congress has recently completed a three

Corresponding Author: John N. Veenstra, School of Civil and Environmental Engineering, Oklahoma State University, 207 ES, Stillwater, OK 74078 
year process that culminated in the draft bill Law of the Hydrological Resource. The act would impose a tribute on the consumption of potable water, a water canon or tax whose revenues would be used in part to augment the budget for the $\mathrm{ESP}^{[2]}$. The purpose of this article is to analyze that regulation as a solution to the problem of deforestation in Costa Rica, by comparing it to another option, based on aspects of technical practicability, economic efficiency, political feasibility, administrative implementability and stakeholder acceptability ${ }^{[7]}$ and subject to the perceptions or frames through which key stakeholders perceive the problem and its potential remedies ${ }^{[5]}$.

The problem of deforestation in costa rica: In 1775 the governor of the province of Costa Rica, under Spanish rule at the time, issued a proclamation discouraging controlled burns on the basis that too much land was being cleared and causing soil sterility. In 1846, several decades after independence, a decree stating the prohibition to cut trees near some key waterways was proclaimed ${ }^{[20]}$. The phenomenon of deforestation is not new. It happens when a land owner chooses to cut the forest to make room for something else, or when squatters trespass on a property illegally for tree logging. The following paragraphs describe some of the current land uses that compete with the forest in Costa Rica and some of the factors that can influence a private owner towards conservation.

Illegal deforestation: Unlawful logging began to take significant proportions in Costa Rica during the middle of the 20th century, due to population growth, the unstable job market in banana plantations, the lack of a rural development policy and lax property rights. In 1941 a law would allow possession of up to 300 hectares of land as long as the occupant cleared at least half of it and maintained cattle at the minimum rate of one animal for every 5 hectares. Those improvements would give the landholder a chance to obtain title, but many of them never cared to get their land registered ${ }^{[3]}$.

In 1961 the Institute of Lands and Colonization was created to help individuals with no land who were looking for a place to live. Tax sanctions were imposed on owners not cultivating their land (that regulation was not abolished until 1977), while squatters were given access to some areas where they were allowed to practice agriculture. The problem was not well controlled until the mid-1980s, when environmental education and fund raising were successful in helping those individuals relocate away from protected and privately owned areas ${ }^{[10]}$. Illegal deforestation in Costa Rica still occurs sporadically, but not as before. The issue has been reduced to controllable levels and that is why its influence in the overall deforestation problem can be considered weak.

Urbanization: Urbanization was a major driver of deforestation during the first half of the 20th century in the Central Valley, where two thirds of Costa Ricans live and where political and industrial centers are located. Outside of that region the weight of urbanization in the current landscape is not that significant. Moreover, this phenomenon is not expected to be a determining factor for the future of the last remaining private forests, because the population is expected to cease growing later this century, (the fertility rate today is just at replacement level). Immigration, often illegal, needs to be considered, but in the great scheme of things it is not expected to be a strong driver for the demand of urbanized land ${ }^{[15]}$.

Forestry: In 1987 the exportation of logs and unprocessed timber was banned, depressing domestic wood values to a fraction of international prices, weakening reforestation incentives and subsidizing inefficient wood production industries ${ }^{[13,19]}$. The government then established a reforestation and forest exploitation incentive to energize that activity, but pressure from Non-Governmental Organizations (NGOs) has weakened that policy instrument. Those who are interested in reforesting purely for conservation complain that the subsidies given are too small, while activists complain that forestry is profitable without any incentive and therefore taxpayers' money should not be spent in subsidizing it. According to the experts that were interviewed, although forestry continues being a viable economic activity in the country, it is no longer growing, primarily because the cost of land in Costa Rica has made it less profitable than before.

Agriculture: Coffee was the driver of Costa Rica's economic development from the middle of the $19^{\text {th }}$ century through the third quarter of the 20th century. Bananas were introduced in the early 1900s and agriculture was diversified in the 1950s. Another diversification wave occurred in the 1980s with the introduction of fruits, flowers and other non traditional products $^{[23]}$.

The harsh reality of the international coffee and bananas markets has taken growers through violent ups and downs and it has forced some of them to go out of business. In a monopsony with increasing producer competition prices can change drastically and growers are destined to loose. Agriculture continues being an 
important economic activity in Costa Rica, but it has fallen behind tourism and manufacturing and nowadays it no longer poses a significant threat against conservation $^{[3]}$.

Pastures for raising cattle: All authors agree in that deforestation in Costa Rica has been driven primarily by the expansion of pastures to raise cattle to satisfy external beef markets ${ }^{[3,4,6,10,11,14]}$. From 1956-1982 the funds used to provide credit to support ranching rose from $13.8 \%$ of total state credit to $23.3 \%{ }^{[14]}$.

But towards the end of the 1990s competition from other countries and a subsequent decrease in international prices forced a significant reduction in the production of cattle in Costa Rica. Today the beef sector is hoping to grow its production again by differentiating its product under the category of organic and by increasing exports after free trade agreements are signed.

The decision to reforest or not, or to deforest or not, is based on what the expected benefits of forested land are, as much as it is based on the expected benefits of deforested land. A few of the benefits of conservation are explained below.

Recreational values: Ecotourism emerged during the 1990s as a great incentive to conservation. By 1994 tourism as a whole was the major earner of foreign exchange $^{[3]}$ and today that sector generates $20 \%$ of the country's foreign income. It represents 5\% of Costa Rica's gross domestic product and it employs about $12 \%$ of its labor force ${ }^{[17]}$.

These days it is not uncommon for land owners to cater to ecotourists on their own forests. On occasions, neighbor associations have joined forces to purchase small tracts of land for conservation and recreation. That has represented a more stable source of income when compared to growing crops ${ }^{[1]}$.

Tourism of course has potential dangers associated with negative environmental impacts. One attempt to prevent its possible damaging effects was the creation in 1997 of a Certification of Sustainable Tourism (CST) by the Costa Rican Tourism Board (ICT), which is a performance-based, voluntary environmental program. CST was designed by a partnership of academic institutions, the major hotel trade association and some environmental NGOs. By 1999115 hotels had decided to enroll in the program and 52 had been audited and given a rating. By 2000 ICT began including CST in its international advertisements and the World Tourism Organization decided to adopt the Costa Rican program as its voluntary environmental certification ${ }^{[17]}$.
Bio-prospecting: In Costa Rica national parks have a relatively low human impact and they are well suited for research, contrary to the case of most of the US, Europe or Africa. In 1992-1993, Merck paid \$1 million to the National Biodiversity Institute (INBIO) for an agreement to conduct research on potential drugs derived from the country's biodiversity to cure a few specific diseases ${ }^{[10]}$. Other bio-prospecting deals are underway and both state owned and private preserves regularly host researchers and charge them fees. The 1997 Biodiversity Law was aimed at conserving biodiversity, promoting its sustainable use as a resource and distributing in a fair manner its associated costs and benefits. The law declares that biodiversity is the property of the state ${ }^{[18]}$.

Carbon sequestration and storage: Up to $70 \%$ of the benefits from forest preservation in Costa Rica accrue to the global community through carbon sequestration $^{[3]}$. This is where the debt for nature swaps and other similar initiatives come to play. The swaps were an idea proposed by a group of international environmental NGOs that were successful at enlisting the participation of a few donor governments and several recipients. During the early stages of that program fifteen countries participated and Costa Rica alone obtained one third of all the funds, in part because it had a significant institutional capacity and a large network of NGOs willing to help and put pressure on the government. By 1991, over $\$ 40$ million had been erased from the country's debt through that mechanism $^{[13,20]}$.

The Costa Rican Office for Joint Implementation (OCIC) was created during the mid-1990s for the issuance of carbon bonds to be traded following the scheme proposed by the Kyoto protocol. A few transactions have already taken place: in 1997 Norway paid Costa Rica two million dollars for the sequestration of 200,000 tons of carbon. The following year, the Dutch government received a carbon bond equivalent to $\$ 673,000$ it paid for projects aimed at reducing methane emissions and the next year they put up another $\$ 334,000$ for carbon fixation. Twenty year carbon storage certificates issued by Costa Rica, valued at between $\$ 40$ and $\$ 80$ million, are currently being marketed at the Chicago Mercantile Exchange and the ratification of the Kyoto Protocol may bring several buyers in the near future ${ }^{[16]}$.

Government incentives: The 1996 amendments to the Forestry Law resulted in the creation of new incentives for conservation that were established to compensate landowners for the environmental services provided by 
their forested lands. The environmental service payment is offered at a rate of $\$ 510 \mathrm{ha}^{-1}$ for reforestation, to be given during the first five years of a 20 year contract. For sustainable forest management the rate is $\$ 310 \mathrm{ha}^{-1}$ and finally $\$ 230 \mathrm{ha}^{-1}$ are paid for forest preservation and natural regeneration for five year contracts ${ }^{[3]}$. Many of the recipients of those payments are NGOs. In 1997 alone, \$14 million were paid for environmental services covering some 100,000 ha. The law includes in its definition of environmental service carbon sequestration and storage and the protection of watersheds, biodiversity and ecosystems $^{[6]}$. Although some activists complain that the amounts given are too small, today there are more applicants for the benefit than recipients and consequently an increase in the ESP funds would be able to prevent further deforestation ${ }^{[22]}$. The next section reflects on the current conservation policy context and whether it is conducive for the implementation of a regulation that would increase the ESP funds or not.

\section{MATERIALS AND METHODS}

Problem Framing: The analysis is based on a series of interviews that were conducted during 2004 and that included representatives from academia, the central government, municipal governments, national and local activists, ranchers and owners of private preserves (Table 1). To analyze the perceptions surrounding the problem of deforestation in Costa Rica, a series of concept maps or frames were created from semi- structured interviews in which different stakeholders expressed how they understand the issue, its components, the relationships among them and the potential solutions ${ }^{[5]}$. The interviewees were selected based on political or rational authority. All the participants hold some position of authority within organizations that participate in policy deliberation. People from both the capital city and a rural area were chosen, but not all regions of the country where incorporated and the process did not consider demographic variables. The Nosara watershed, in the North-West of Costa Rica was selected as the rural area and it is considered as a valid case for the study of deforestation because the biggest proportion of cattle ranches in the country are located there and that area suffered the most intense deforestation during the 1980s and the most significant recovery during the past few years. A major fraction of the forests in private hands are located in that region. However, other locations in the country may have slightly different dynamics and the agriculture, urbanization, forestry and tourism components may mix differently in each place.

\section{RESULTS}

Each group of interviewees, along with their associated motives and trust judgments, is portrayed in Table 2. The major observation that can be drawn from the list is that trust is pervasive, except on the side of the NGOs, which distrust the central government's competence and degree to which they act in the public's interest. They also distrust the private sector's honesty.

Table 1: List of experts interviewed

\begin{tabular}{|c|c|c|c|}
\hline Name & Title & Affiliation & Organization type \\
\hline Germán Rojas & $\begin{array}{l}\text { President, Environmental } \\
\text { Matters Commission }\end{array}$ & Congress & Central Government \\
\hline Edwin Estrada & $\begin{array}{l}\text { Advisor in Environmental } \\
\text { Matters }\end{array}$ & PUSC political party & Political party \\
\hline Marco A. Corrales & $\begin{array}{l}\text { Advisor in Environmental } \\
\text { Matters }\end{array}$ & PLN political party & Political party \\
\hline Wadi Mejías & Officer & Hojancha Municipality & Local government \\
\hline Danilo Méndez & Sub-regional chief & $\begin{array}{l}\text { Environment Ministry } \\
\text { Hojancha }\end{array}$ & Regional government \\
\hline Gilberto López & Officer & $\begin{array}{l}\text { Agricultural Ministry } \\
\text { Hojancha }\end{array}$ & Regional government \\
\hline Miguel Méndez & Manager & Monte Alto Preserve & Private sector-conservation \\
\hline Wilmarth Matarrita & President & Fedeagua & Local NGO \\
\hline Juan Figuerola & Coordinator of forest issues & FECON & National NGO \\
\hline Dr. Edgar Ortiz & Representative & FONAFIFO & Scholar \\
\hline Alvaro Monge & Agriculture coordinator & Intl. Commerce Ministry & Central Government \\
\hline Miguel Vallejo & Manager of consulting services & Fundacion Neotropica & National NGO \\
\hline Carlos Sandí & Professor & EARTH University & Scholar \\
\hline Gerardo Vargas & Representative & Corfoga & Private sector \\
\hline Ronald Guerrero & General Manager & Precious Woods & Private sector \\
\hline
\end{tabular}


Am. J. Environ. Sci., 5 (2): 145-155, 2009

Table 2: Actors, their motives and their trust judgments

\begin{tabular}{|c|c|c|}
\hline Policy actor & Motto/motives & Trust judgment \\
\hline Central government & Save the country-maximize benefits for all & $\begin{array}{l}\text { No evidence of distrust toward other actors. Sees itself } \\
\text { as open and receptive. Working on "continuous } \\
\text { improvement". }\end{array}$ \\
\hline Local government & Save the county-progress for all & $\begin{array}{l}\text { No evidence of distrust to any other actor, but some } \\
\text { reservations with respect to the central government. } \\
\text { Sees itself as provider of the people. Interested in } \\
\text { citizen's economic progress and county development. }\end{array}$ \\
\hline National NGO & Save the forest-nature is to be protected & $\begin{array}{l}\text { Distrusts both industry and the government, but } \\
\text { satisfied with participation opportunities and has been } \\
\text { able to influence other stakeholders in the past. }\end{array}$ \\
\hline Regional NGO & Save the people-nature sustains people & $\begin{array}{l}\text { Distrusts both industry and the government, but } \\
\text { satisfied with participation opportunities and has } \\
\text { been able to influence other stakeholders in the past. }\end{array}$ \\
\hline $\begin{array}{l}\text { National cattle } \\
\text { growers organization }\end{array}$ & $\begin{array}{l}\text { Save the ranchers-ranching is } \\
\text { good for the country }\end{array}$ & $\begin{array}{l}\text { No evidence of distrust to any other actor. Works to } \\
\text { improve productivity and conducts production } \\
\text { research. }\end{array}$ \\
\hline $\begin{array}{l}\text { Local private } \\
\text { cattle producer }\end{array}$ & $\begin{array}{l}\text { Save the ranchers-ranchers have } \\
\text { a right to their way of life }\end{array}$ & $\begin{array}{l}\text { Slight distrust towards central government, but overall } \\
\text { satisfied with the status quo. }\end{array}$ \\
\hline $\begin{array}{l}\text { Local private } \\
\text { preserve }\end{array}$ & $\begin{array}{l}\text { Save the forest-protecting the } \\
\text { environment is a good thing }\end{array}$ & $\begin{array}{l}\text { No evidence of distrust to any other actor. Satisfied } \\
\text { with the status quo. }\end{array}$ \\
\hline Academia & Save the country-sustainable development is the key & No evidence of distrust to any other actor. \\
\hline
\end{tabular}

But that mistrust is not reciprocal. The central government has taken into account the views of activists in the past and they recognize them as legitimate players in the policy-making process and that is acknowledged by NGOs themselves. The private sector is also not overly concerned with activists, which are seen as part of the political landscape, but not as a threat. The local government also has some reservations about some of the policies supported by the central government.

The context for a deforestation policy is one that first of all acknowledges the progress made in the country so far, in particular since the passing of the Forestry Law amendments of 1996. Since deforestation on private lands is practically banned, the real question is whether something can be done to increase the current amount of forest, particularly in highly unfertile, sloped, erodible terrain.

Another contextual dimension is that of the role of the state. The conservation policy of the 1970s and 1980s was based on a clearly interventionist drive by which the state would expropriate vast tracts of land that would then be converted into National Parks. Many of those expropriations have not yet been paid in full to former land owners and considering that more than $25 \%$ of the country is already under some type of preservation status, the current intent of the state is that of enabling and facilitating conservation by the private sector, instead of doing it themselves ${ }^{[21]}$.

Actors, their motives and their trust judgments: The contemporary environmental policy history of Costa Rica suggests that lack of inclusiveness has been responsible for mediocre and ineffective solutions in the past. The alliance between the central government and the scientific community has always been strong. The role of the private sector has been irregular and in terms of conservation their input has not been the determining factor in policy discussions, until recently. Also recent has been the role played by $\mathrm{NGOs}^{[10]}$. Any relevant move to perpetuate the conservation gains of the past few years and make deforestation policy robust in Costa Rica will have to be inclusive. A suitable stakeholder participation strategy would avoid extremes such as pre-emption or exclusive third party mediation. In the present case consultation seems to be the best approach, with the government taking the lead in the process, using academia as an objective technical resource and making an effort to obtain and consider input from activists and the private sector.

The concept maps of different stakeholder groups are explained in the following paragraphs. Figure 1-4 were created by listing all the main terms or subjects mentioned by the interviewees and writing them on rectangles of three different sizes, according to how frequently they were mentioned during the conversation and how much importance was given to each of them by the stakeholder. The rectangles were positioned such that related concepts are close to one another. Arrows were used occasionally to show relationships emphasized by the participants.

Figure 1 suggests that the Costa Rican Federation for the Protection of Nature (FECON) considers the ESP a good policy instrument and they emphasize the need to expand it through the revenues the water canon component of the Hydrologic Resource Law would 


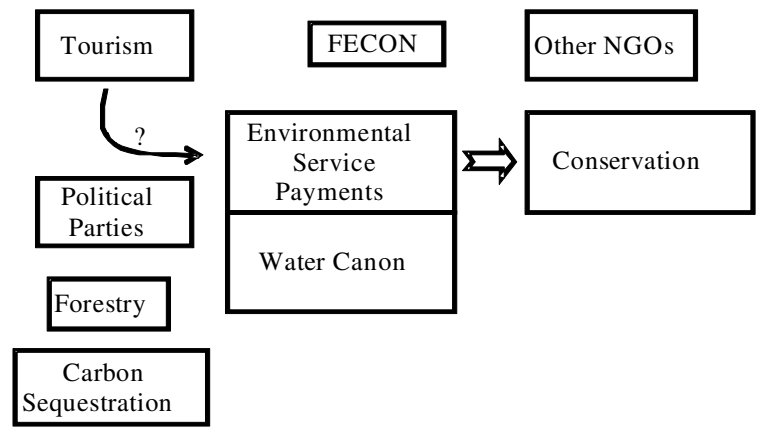

Fig. 1: The frame of a national NGO
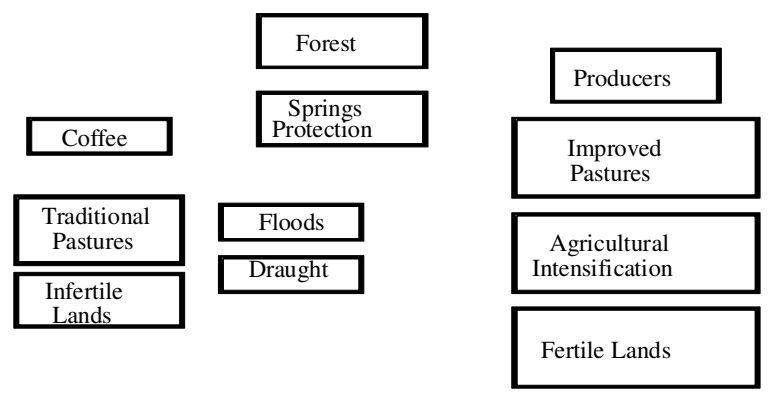

Fig. 2: The frame of the cattle sector

generate. They also see the need to force the tourism industry to contribute to the ESP fund, because they are major beneficiaries from the protection of nature in general. More than $75 \%$ of the tourists in Costa Rica express that their major reason for choosing that destination is its natural beauty ${ }^{[10]}$.

The view of FECON with respect to the role of the political parties and the difference between the two major ones is that their role has been irregular and inconsistent, for example they support the ESP but also massive tourism, which can be detrimental for the environment. The role of the government is accepted as that of a policy-maker with the legitimacy to establish regulations and enforce them, but there could be a potential conflict if prominent NGOs in Costa Rica continue feeling that the actions of the government are contradictory and insufficient. With respect to the role of forestry, FECON accepts it as a viable and legitimate economic activity, provided that no taxpayers' money is spent subsidizing them.

Figure 2 conveys the message from the cattle sector: problems related to deforestation do not stem from grasslands per se, but from improperly managed ones, corresponding to the traditional pastures rectangle on the left of the diagram, shown in stark contrast to the improved pastures block on the right. Their view is that farms that utilize good seeds, rotation and otherwise

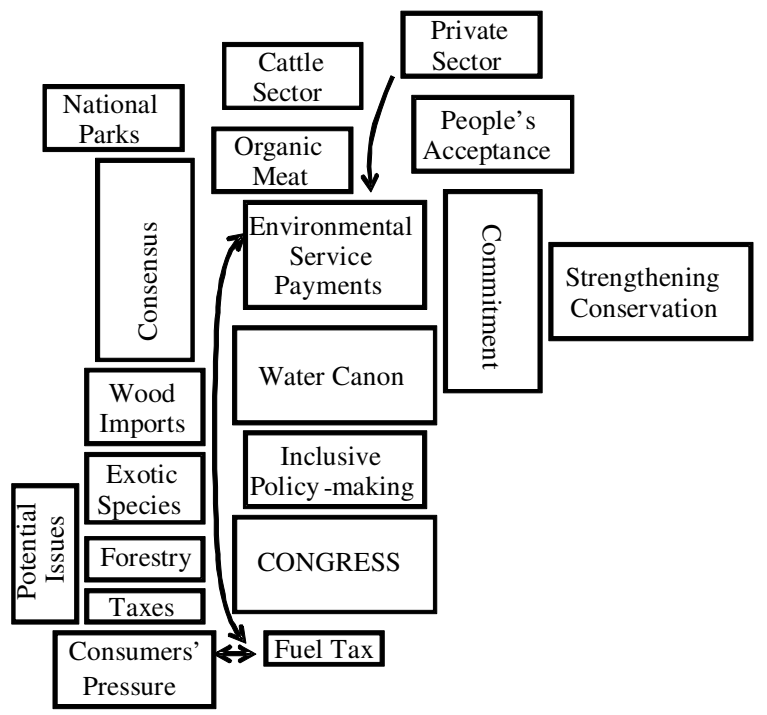

Fig. 3: The frame of congress

modern and sustainable techniques have only benefits for the community, but unfortunately still today many ranchers operate in a sea of ignorance where infertility, overgrazing, low yields and pollution are common.

Figure 3 is the result of a high degree of consistency in the opinions expressed by leaders from the major political parties and a congressman, who emphasize the strong degree of consensus in Congress around environmental matters. The major parties see the ESP as something to be fortified with the water canon, but they also recognize the role, value and importance of different sectors in society, like the cattle sector and the forestry sector, that can prevent undesirable wood imports.

The congressional apparatus sees itself as committed to the protection of the environment, proud of the progress made so far with successes such as the consolidation of the National Parks System and excited about the prospects of the draft bill Law of the Hydrologic Resource and its water canon component, which has been distilled from a lengthy participatory process through which several sectors in society were consulted. Public acceptance of congressional actions is important to them.

The government is also thinking about ways to motivate or force the private sector in general so they make contributions to the ESP. The national electricity distribution agency has been voluntarily donating funds to the ESP for a few years, because most of the electricity in Costa Rica comes from hydroelectric dams, fed by water stored in forests.

Figure 4 combines the views of a municipal government and rural offices of the agriculture and the environment ministries. 


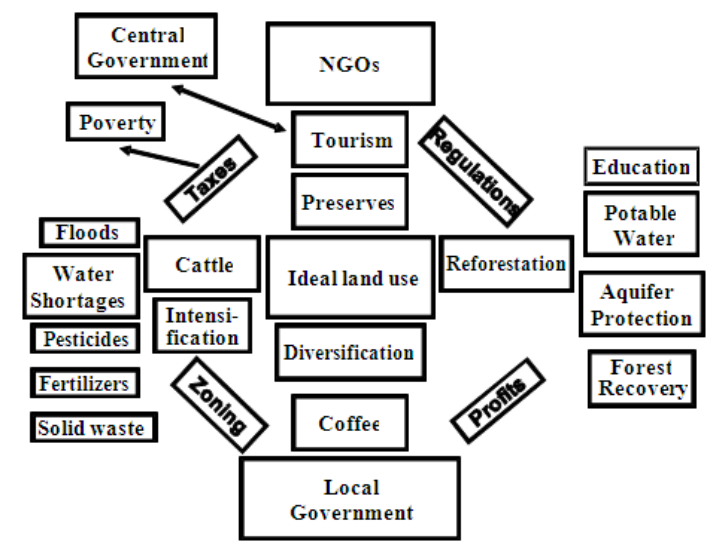

Fig. 4: The frame of the local government

For them, the current land use is very close to being ideal. The current situation is the result of the interests of the private land owners and the implementation of effective regulations (including zoning and taxes). They see as positive and relevant the diverse existing land-uses and their associated benefits. The advantages of a balanced land-use pattern are listed on the right of the map. One case of policy consensus and one of policy conflict can be drawn from this figure. The first one is the beneficial and prominent role that the local government gives NGOs, which are regarded as allies in the protection of the environment and the quest for sustainable development. The second one is the dissenting view with respect to some of the policies promoted by the central government, like massive tourism. There is a visible gap between the central and the local governments and legitimate policy will require at least a partial closure of that gap.

Other observations from the figure include the view that taxes have to be regarded carefully, because the standard of living of citizens in remote locations is often low and additional dues could draw people further into poverty. And finally, problems other than deforestation are regarded as more important for the locals and those appear on the left of the map.

\section{DISCUSSION}

The aggregate map is shown in Fig. 5. Society appears in the middle, as the entity that is composed of the actors previously described and others and as the unit that debates between allocating land to conservation (right side) or other uses (left side). Conservation is in general seen as a good thing, while most actors tend to discuss other land uses in a negative way,

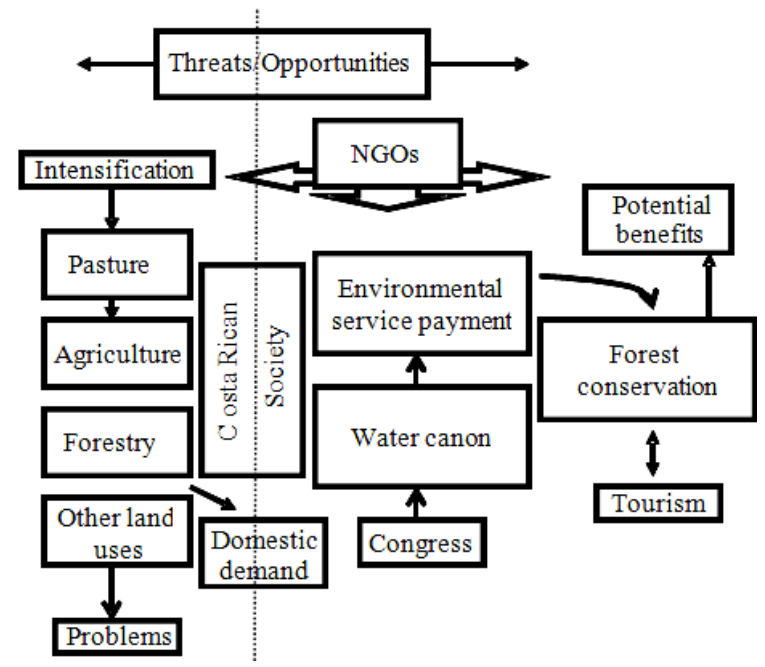

Fig. 5: Aggregate map

or in a way that accepts them as valid but not preferable to conservation. The case of domestic demand for wood potentially becoming larger than supply stands out from the forestry rectangle, because it is a preoccupation of several people. A crisis in the forestry sector could lead to the unwanted situation of importing wood.

Environmental Service Payments are seen as a good thing that should be augmented with the water canon, something in the hands of Congress and supported at large by those who know about it. Tourism is both a beneficiary of conservation and a potential promoter or detractor of it, depending on whether it is done in an environmentally sound way or not. Finally, NGOs appear represented in a prominent way as watchers and influencers of everything related to the dilemma of land use decisions and policies.

The main areas of disagreement apparently are between local and central governments and between NGOs and the central government. Since Congress is the one taking the lead in proposing legislation to strengthen conservation, it is imperative that the views of municipalities, ministry branches and NGOs be taken into consideration. The major potential consensus will take place among ranchers, local government offices and NGOs.

Policy alternatives: The two policy alternatives were chosen from a review of the conservation history of Costa Rica and from the opinions of experts consulted. The first one consists in increasing the funds for conservation subsidies, like the water canon intends to do through the Hydrologic Resource Law by imposing a tax on the consumption of potable water. 
Am. J. Environ. Sci., 5 (2): 145-155, 2009

Table 3: Policy alternatives ranked against legitimacy criteria

\begin{tabular}{lllll} 
& & & Superior policy \\
No. & Legitimacy criteria & Objective & Increase subsidies & Tax ranching \\
\hline 1 & Technical implementability & Turn infertile, sloped, erodible land into forest & $\sqrt{ }$ \\
2 & Technical implementability & Increase forested land in private hands & $\sqrt{ }$ & - \\
3 & Economic efficiency and administrative & Minimize expenses for the government & - & \\
& implementability & Utilize tested policy instruments & $\sqrt{ }$ \\
4 & Political feasibility & Maximize acceptance of the policy & & $\sqrt{ }$ \\
5 & Stakeholder acceptability & & \\
\hline
\end{tabular}

An alternative aligned with the drive by the government to avoid pure command and control is to increase the cattle production tax on marginal lands. Other types of more recent and complex regulatory instruments, such as tradable permits, are excluded from the analysis due to the lack of experience with them in Costa Rica.

Table 3 shows the ranking of the two alternatives according to legitimacy criteria and associated goals ${ }^{[7]}$.

Technical implementability: The ability of the policy to achieve its major intended goal is explored here. The first objective is the most important one, since it would turn areas of low productivity and prone to high pollution loads into forests. The second objective is also relevant and it stems from the general desire by the government and other stakeholders to continue recovering the forest that was lost to pastures during the second half of the 20th century. There are obvious constraints to forest expansion, such as the societal need to satisfy to the extent possible the food and housing requirements of the citizenry and the fact that forest in some locations can not grow due to climatic and soil conditions. Values, customs and perceptions also play a role in the decision-making process of the land owner. Even after the implementation of policies aimed at influencing the private sector towards conservation, some individuals will continue keeping their farms.

The ESP however would make conservation more attractive for ranchers operating at low profitability levels and therefore it is considered a technically feasible solution to increase forested land. The tax on marginal lands could also work by discouraging the production of cattle in those locations, with the added benefit of revenue generation for local governments.

However, an increase in the property tax is not as likely to influence a farmer as much as an incentive. The tax increase can prompt the farmer to negotiate with the authority the valuation of the property (the tax is based on property values), to look for ideas to maintain profitability and to complain. The ESP offers something in exchange for abandoning the grassland and letting it recover into forest: a constant stream of revenue. It is also important to consider that although grassland is the major competitor of forest in Costa Rica, it is not the only one. The tax on cattle production attacks the biggest problem, but not the only problem, while the subsidy for conservation has a wider scope, promoting conservation in many places, not only around pastures. The water canon is therefore considered a superior policy from the technical implementability perspective.

Economic efficiency and administrative implementability: Decisions are made in a context of scarcity and so the policy maker should be concerned about obtaining the biggest return for the minimum expense. Also, a policy that is perceived as efficient may gain higher acceptability than one that is not.

The increase in government expenses with the implementation of the Hydrologic Resource Law would be minimal, since the ESP and its administrative agency already exist. The program would simply have to establish a procedure whereby the money collected through the water canon is channeled from the water suppliers to them. The law calls for the creation of a new agency that would assume all the duties related to water use, but its staff would be composed of individuals currently working for other agencies that up to now have had partial responsibilities with respect to water issues. Also, since the law creates a new tax on the consumption of potable water it is expected that administrative expenses would be paid by the new revenues.

A similar reasoning applies to the tax on marginal lands: municipalities collect and administer property taxes in Costa Rica and the program proposed here is simply a modification of such existing mechanism. The increase in government expenditures is therefore expected to be minimal in both cases and as a consequence, both alternatives are considered equal from the perspective of economic efficiency and administrative implementability.

Political feasibility: For the past several years, Congress has lost interest in purchasing land to convert 
it into State-owned protected areas. Improvements in conservation are wanted, but through non-interventionist policies. Also, cattle production is perceived by most stakeholders as a viable and needed economic activity in the country and therefore the use of pure command and control to force ranchers to abandon their lifestyle would not be supported by many.

Neither alternative is putting strict, specific limits on the grassland coverage in the country, but a tax that is automatically converted in a subsidy for conservation that can positively affect the entire country is a far more reaching and benign policy instrument than simply a tax that will affect a few and can be perceived by the far right as unjust and an attack on free enterprise. The increase in the subsidy budget is therefore considered superior in that respect to the tax on marginal lands.

Stakeholder acceptability: Since the Hydrologic Resource Law would impose a tax on drinking water, people living under the poverty line would be the most affected, but there could be an exemption for the first several liters consumed per month, so as not to affect the most disadvantaged. The regulation has been widely discussed and it is a good example of participatory policy-making. Also, according to Steinberg ${ }^{[20]}$, a survey conducted during the mid-1990s concluded that $91 \%$ of Costa Ricans were willing to pay more for electricity and water if the additional money was to be used for biodiversity conservation. Therefore, it can be envisaged that people's satisfaction with this alternative will be high.

The tax on marginal lands would be harder on small, low revenue farms. Those who decide to abandon cattle production would have to be helped in finding another way of making a living and the design of such a compensation mechanism would minimize resistance against the policy. That is not unreasonable and it has been done in the past. Esposito ${ }^{[9]}$ for example, discusses at length the case of integrative conservation in an area of the North West of Costa Rica in which former farmers became park rangers or tourism entrepreneurs when their lands were expropriated to expand a conservation area. Another issue related to the tax may be a potential increase in the price of domestic beef. If the area dedicated to pastures decreases, supply may become limited forcing the price up. But the drive by the government to promote agricultural intensification on fertile lands may counter-balance that scenario. The tax would affect only a relatively small number of people, while the benefits would accrue to society at large and therefore this alternative is considered superior to the water canon in terms of stakeholder acceptability.

\section{CONCLUSION}

Taxing cattle production in marginal lands is superior to increasing conservation subsidies only with respect to one objective, while increasing the subsidies for conservation is superior with respect to three objectives and there is one tie in the analysis.

Although increasing taxes on marginal lands is a viable alternative that might enjoy wider acceptance by most stakeholders, the Hydrologic Resource Law is a superior policy because it is expected to be more effective in reaching the goal of converting all remaining pastures in fragile lands to forest and increasing the total forested area in private hands. Both alternatives are less interventionist than pure command and control, none of them is expected to increase real government expenditures and both are policy instruments that have been tested in the past with relative success.

The draft bill is seen in a positive way by the two major political parties, the main NGOs and academia and therefore it is expected that it will convey political benefits to the policymakers, considering that a strong opposition is not likely from any important constituency. The bill was a prominent part of two of the four individual concept maps and the aggregate map presented in results and discussion sections and the policy would not conflict with existing regulations or administrative agencies.

This study has shown that the views from the major stakeholders about the problem of deforestation in Costa Rica are conducive to the successful implementation of the Hydrologic Resource Law as a policy to strengthen conservation in the country. Its water canon component is a superior regulatory instrument when compared to the alternative of increasing taxes on marginal lands.

The problem of deforestation in Costa Rica is primarily about observable facts. Values play a role, but one that supports facts in that Costa Ricans are in general supporters of conservation. Trust in experts is therefore high. Moreover, about $80 \%$ of Costa Ricans understand the value of conserving forests for water storage $^{[6]}$, indicating that social trust is also high. Trust in the government, on the other hand, tends to be low. Although people tend to remember some of the highlights of past administrations, in general the government is perceived as favoring the interests of a few and lacking implementation skill. Policy-making under this context needs to be articulated by experts with little stakeholder involvement and then the government adopts the regulation ${ }^{[12]}$. The process that culminated with the draft bill for the Hydrologic 
Resource Law was more inclusive and perhaps that explains why three years of revisions were needed, but that enriched the outcome and it should prevent postadoption critiques. The key to maximize stakeholder satisfaction is to educate the citizenry about the program and to publicize its benefits once they are measurable. People will need to perceive that the extra amount they pay for potable water is truly serving a purpose that benefits the country in a significant way.

Other considerations regarding the specific program design are worth mentioning. For example, an initial investment will be needed in education, coordinating the tax collection work of water suppliers, defining how the new monetary resources will flow into the agency managing the ESP and planning how the new budget will be utilized for new and longer conservation contracts. Before the new tribute starts generating funds there will be some expenses that will need to be accounted for. The policy should also include a revision period that would force the executive branch to evaluate results and propose improvements. Such clauses have been rare so far in the Costa Rican legal codes ${ }^{[18]}$. And finally, a process for obtaining feedback from stakeholders should ideally be included in the ruling.

The current political landscape in Costa Rica makes the timing for a congressional discussion and approval of the Hydrologic Resource Law very uncertain. From the first time since the foundation of the Second Republic in 1949, the 2002 general elections saw the emergence of a third prominent party, whose views on environmental matters are to this day unclear. Although they are still far from being able to mobilize the majority of the electorate, their existence can no longer be ignored and congressional negotiations will have to include them. The timing for a discussion of the law in Congress it is not predictable, considering that matters such as tax reform and the ratification of free trade agreements are using up most of the legislative time and taking into account that continuity is a challenge in a country where serving in Congress two consecutive terms is prohibited.

Will the Hydrologic Resource Law ever be implemented? The consensus about its benefits and the support from major stakeholders are not enough. Although Costa Ricans support environmental legislation, they are more concerned about poverty alleviation, corruption prevention and crime reduction. The leadership of concerned policy-makers and activists will be tested in the upcoming months. If they succeed, a historical milestone in the conservation history of Costa Rica will be reached.

\section{ACKNOWLEDGMENT}

The researchers would like to thank the interviewees who participated in this study for their openness, their willingness to help and for the unselfish way in which they shared their time to discuss the complex deforestation issue.

We would also like to thank Dr. James Lawler and Dr. Will Focht at Oklahoma State University for their insights for and revisions of this study.

\section{REFERENCES}

1. Andrade, Z., 2004. Tiquicia Reinvents Itself La Nación.

2. Asamblea Legislativa, 2005. Law of the Hyrological Resource. (Unpublished document). San José, Costa Rica.

3. Brockett, C.D. and R.R. Gottfried, 2002. State policies and the preservation of forest cover: Lessons from contrasting public-policy regimes in Costa Rica. Latin Am. Res. Rev., 37: pp 7-40 http://cat.inist.fr/?aModele $=$ afficheN\&cpsidt= 13536800

4. Brown, L.R. 1990. The Illusion of Progress. In: State of the World 1990, Brown, L.R. (Ed.). Worldwatch Institute, Washington, DC., ISBN: 0393306143, pp: 270.

5. Bryson, J.M., 1995. Strategic Planning for Policy and Non-Profit Organizations. 1st Edn., JosseyBass Publishers, San Francisco, ISBN: 0787901415, pp: 352.

6. Castro, E. and G. Barrantes, 1999. Revenue Generation Through the Sustainable Use of the Environmental Resources From Costa Rica's Biodiversity. (Unpublished document). Instituto Nacional de Biodiversidad. San José, Costa Rica.

7. Clemons, R.S. and M.K. McBeth, 2001. Public Policy Praxis Theory and Pragmatism: A Case Study Approach. 1st Edn., Prentice-Hall Inc., New Jersey, ISBN: 0130258822.

8. Corporación de Fomento Ganadero. 2000. National Cattle Census. (Unpublished document). San José, Costa Rica.

9. Esposito, L., 2002. Integrative conservation. SAIS Rev., 22: 53-75.

http://muse.jhu.edu/journals/sais_review/v022/22.2 esposito.html

10. Evans, S., 1999. The green republic: A conservation history of Costa Rica. 1st Edn., University of Texas Press, Austin, ISBN: 0292721013 , pp: 335. 
11. Goodstein, E.S., 2001. Economics and the Environment. 3rd Edn., John Wiley and Sons, New York, ISBN: 0471399981, pp: 560.

12. Hartwick, J.M. and N.D. Olewiler, 1998. The Economics of Natural Resource Use. 2nd Edn., Addison-Wesley Educational Publishers, Inc., Massachusetts, ISBN: 0321014286, pp: 432.

13. Keohane, R.O., 1996. Analyzing The Effectiveness Of International Environmental Institutions. In: Institutions for Environmental Aid: Pitfalls and Promise, Keohane, R.O. and M.A. Levy (Eds.). The MIT Press, Cambridge, Massachusetts, ISBN: 0282112132.

14. Lutz, E. and H. Daly, 1991. Incentives, regulations and sustainable land use in Costa Rica. Environ. Resour. Econ., 1: 179-94. DOI: 10.1007/BF00310017

15. Proyecto Estado de la Nación, 2003. State of the Nation in Human Sustanable Development. San Jose, Costa Rica, pp: 91-98.

16. Ramirez, O.A., 2000. The Carbon Cycle and the Value of Forests as a Carbon Sink: A Tropical Case Study. In: Sustainable Forest Management and Global Climate Change: Selected Case Studies from the Americas, Dore, M.H.I. and R. Guevara, (Eds.). Edward Elgar Publisher, Northampton, ISBN: 1840641615, pp: 296.

17. Rivera, J., 2002. Assessing a voluntary environmental initiative in the developing world: The Costa Rican certification for sustainable tourism. Policy Sci., 35: 333-60. DOI: 10.1023/A:102137011105
18. Sagot, A., 2000. Environmental Legislation Manual: Annotated Organic Environmental Law, With Constitutional Jurisprudence and Related Legislation in Addenda. Investigaciones Jurídicas SA, San José, Costa Rica.

19. Southgate, D., 1995. Economic Progress and Habitat Conservation in Latin America. In: The Economics and Ecology of Biodiversity Decline: The Forces Driving Global Change, Swanson, T.M. (Ed.). Cambridge University Press, Cambridge, England, pp: 91-98.

20. Steinberg, P.F., 2001. Environmental Leadership in Developing Countries: Transnational Relations and Biodiversity Policy in Costa Rica and Bolivia. 1st Edn., MIT Press, Cambridge, Massachusetts, ISBN: 10: 026269266X, pp: 272.

21. Varela, I. and Corella, 2003. Red Alert in Green Areas. La Nación.

22. Villegas, J. and C. Hernández, 2004. Private Forested Areas Grow. La Nación.

23. Wilson, B.M., 1998. Costa Rica: Politics, Economics And Democracy. 1st Edn., Lynne Rienner Publishers, Inc., Boulder, Colorado, ISBN: 1555874851, pp: 187. 